\title{
Identification of the directions of professional development of heads of schools in the Russian Federation
}

\author{
Sergey Neustroev ${ }^{1}$, Yulia Fedorchuk ${ }^{1}$, and Anna Arinushkina, ${ }^{1, *}$ \\ ${ }^{1}$ Institute of Education Management of the Russian Academy of Education, 105062, 5/16, 1B, \\ Makarenko str., Moscow, Russia
}

\begin{abstract}
The results of the research on the deficiency of professional competencies in school principals with experience of up to 2 years and experienced managers of general education organizations are considered in accordance with the draft of the Professional Standard "Head of an Educational Organization". The revealed dependencies show the main directions of professional development for the directors and justify the activation of work on the formation of the personnel reserve and preparation for the entry into office. Researches were conducted by the staff of the Institute of Education Management of RAO in 2017, heads of 24 Russian regions took part in the on-line survey. The work was carried out within the framework of the State task for the Program of Fundamental Scientific Research of the State Academies of Sciences for 2013-2020 (in the part of RAO) (approved by the Decree of the Government of the Russian Federation of December 3, 2012 No. 2237-r) on the theme: "Theoretical and methodological basis for professional development of managers in education system” (state registration № 27.9385.2017/8.9).
\end{abstract}

\section{Introduction}

Management is a special kind of activity [1-3], based on individual leadership characteristics [4], intuition, professional competences, system personal qualities. And the management system of a modern educational organization [5] is a multifactorial and multidimensional process based on the principles of scientific management, oriented towards modern needs in the field of education and the implementation of public policy. The educational organization refers to social purpose-oriented systems, the effective functioning of which, is defined as "the maximum social effect in the rational use of limited resources» [6,7].

Achieving the goals in this case reflects the implementation of the objectives of education formulated at the national level. The manager must timely take into account the ongoing changes in the society and the economy and, accordingly, build and coordinate their activities [8]. He can not do without knowledge in the field of jurisprudence, economics, financial and personnel records, organization [9] management, theory of personnel management, office work, social and general psychology, pedagogy. This set of requests at times increases the

* Corresponding author: anna.arin@ mail.ru 
requirements for the head of the organization. An error in appointing a leader or in the absence of conditions for its development can easily destroy even the most highly organized and effective system.

The system of additional vocational education, which is the basis of the mechanism for supporting the professional development of managers, is no longer able to cope with this task. A rich cultural and educational environment [10], massive information flows, the availability of specialized information bases, active social partnership of educational organizations [11], creative centres, scientific organizations, cultural institutions, various professional associations - greatly expand the professional horizons of the leaders of organizations. To determine how these elements are embedded in the professional development plans of the current managers and the areas of education that they are in demand at the present stage of the society's development, taking into account the forthcoming implementation of the Professional Standard, it seems important to improve the training and certification system for Russian directors.

\section{Methods}

The Institute of Education Management of the Russian Academy of Education conducted a sociological study on the basis of on-line questioning of the current school principals to identify the lack of personal and professional competencies of the directors in accordance with the introduced Professional Standard, establishing interrelationships between ways to increase compliance with the requirements of the professional standard and models of professional development [12].

The questionnaire consists of two parts, the first part gathers data on the expert and his vision of the preferred options for action aimed at achieving compliance with the professional standard and training methods, the second part is aimed at identifying the needs of directors in the scarce management competencies at the following levels:

- Labor actions causing difficulties;

- Lack of professional skills;

- Lack of professional knowledge;

- Lack of general competence (soft skills).

Actions, skills, knowledge and soft skills are considered in the context of the generalized labor functions presented in the Professional Standard: the management of the educational activities of the educational organization, the management of the development of the organization, the management of resources, the representation of the educational organization in relations with public authorities, local authorities, public and other organizations [13]. The fifth function "Management of research, expert-analytical, developmental, innovative and production activities of the educational organization" for school level is not allocated. The study was carried out through an on-line survey conducted in 2016-2017. and full-time survey of directors within the framework of two All-Russian scientific and practical conferences "Professional development of heads of educational organizations" [14], conducted by the Institute of Education Management of RAO.

\section{Research}

\subsection{Sample}

The survey involved heads of educational organizations, their deputies, as well as heads of research institutes and departments of education management bodies, a total of 625 respondents from 24 constituent entities of the Russian Federation, including cities such as 
Moscow, St. Petersburg, Leningrad, Saratov, Samara, Yaroslavl, Volgograd, Kirov regions, the Republic of Sakha (Yakutia), etc.

\subsection{Processing Results}

Data processing was carried out in the SPSS 17.0 program. using two types of analysis:

- factor analysis (main component method, Varimax rotation with Kaiser normalization);

- frequency analysis.

The hypothesis of the research is the assumption that the revealed directions of professional deficiencies and the ways of their compensation form interrelations with the time in office; the nature of these relationships determines the options (models) of professional development of the head of the educational organization in the context of the introduction of a professional standard.

\subsection{Results of the study}

The results of the factor analysis are presented in Table 1.

Table 1. Results of factor analysis.

\begin{tabular}{|c|c|c|c|}
\hline & \multirow{2}{*}{ Indicators } & \multicolumn{2}{|c|}{ Factors } \\
\hline & & 1 & 2 \\
\hline \multirow{3}{*}{$\begin{array}{l}\text { Ways to } \\
\text { increase } \\
\text { compliance } \\
\text { with the } \\
\text { professional } \\
\text { standard }\end{array}$} & self-development & 0,619 & 0,658 \\
\hline & delegating & $\mathbf{0 , 5 5 4}$ & 0,243 \\
\hline & forming a management team & 0,145 & 0,612 \\
\hline \multirow{8}{*}{$\begin{array}{l}\text { Ways/methods } \\
\text { to compensate } \\
\text { for deficits in } \\
\text { occupational } \\
\text { deficits }\end{array}$} & $\begin{array}{l}\text { traditional system of additional } \\
\text { vocational education }\end{array}$ & 0,494 & 0,234 \\
\hline & conferences, forums, seminars & 0,490 & 0,421 \\
\hline & open online courses & 0,145 & $\mathbf{0 , 5 2 9}$ \\
\hline & webinars & 0,466 & $\mathbf{0 , 8 7 8}$ \\
\hline & coaching & 0,326 & 0,643 \\
\hline & training & 0,347 & 0,721 \\
\hline & deferred education & 0,523 & 0,679 \\
\hline & internships & 0,458 & 0,645 \\
\hline \multirow{3}{*}{$\begin{array}{l}\text { Directions of } \\
\text { professional } \\
\text { development }\end{array}$} & managing educational functions & 0,458 & 0,683 \\
\hline & $\begin{array}{l}\text { managing the development of } \\
\text { educational facility }\end{array}$ & 0,348 & 0,429 \\
\hline & $\begin{array}{l}\text { managing resources of the } \\
\text { educational organization }\end{array}$ & 0,428 & 0,798 \\
\hline
\end{tabular}




\begin{tabular}{|l|l|c|c|}
\hline & $\begin{array}{l}\text { representation of the educational } \\
\text { organization in relations with } \\
\text { state authorities, local self- } \\
\text { government bodies, public and } \\
\text { other organizations }\end{array}$ & 0,736 & 0,267 \\
\cline { 2 - 4 } & $\begin{array}{l}\text { general competencies (soft } \\
\text { skills) }\end{array}$ & $-0,783$ & 0,357 \\
\hline \% Dispersion & 19,382 & 19,158 \\
\hline Cumulative \% & \multicolumn{2}{|c|}{38,54} \\
\hline
\end{tabular}

The first factor can be designated as "Experienced Directors", the time spent in office is more than two years. Accordingly, the accompanying characteristics: the average age is 47 years, the teaching experience is 24 years, the work experience in the managerial position is 12 years; the respondents are representatives of the generations of "baby boomers" and generation $X$ [15-17].

It includes the following indicators:

- orientation to own development and delegation of authority, as a standard management model;

- traditional methods of teaching, is represented by the most preferable way of training the existing DPO system and a convenient format for rapid compensation of deficits - webinars; - directions of professional development, are conscious deficiencies - external communications of the educational organization in the real and virtual community, which is one of the rapidly changing requirements of the professional standard of the head of the educational organization. This group of leaders also highlights the need for improving soft skills, in response to the demands of the modern environment.

The second factor can be called "Young Leader", work experience up to 2 years. The accompanying characteristics: the average age is 36 years, the teaching experience is 9 years, the seniority of work in the managerial position is 4 years; the respondents of the generations $\mathrm{X}$ and $\mathrm{Y}$ are represented. It includes such indicators as:

orientation to their own development and careful selection and improvement of the management team;

orientation on modern electronic forms of education, training skills at trainings, orientation to the best examples of pedagogical and management practices through training on open online courses in Russian and foreign educational institutions, as well as direct practical-oriented training through internships and mentoring;

in connection with small experience, self-evaluation of own needs in building up professional competencies, shows two main areas of competence deficiencies - the management of educational activities and the management of the resources of the educational organization.

The results of the frequency analysis for the three groups of indicators are presented in Figures 2-4.

Based on the results of the factor analysis, two groups of respondents were identified and in order to identify the issues relevant to the newly appointed managers (work experience of up to 2 years) and experienced directors (over two years of experience), the results of the frequency are presented in the context of the responses of the two sample groups. In the first group, "experienced directors", in the second group of respondents - managers with experience of up to two years.

By methods of increasing the compliance with the professional standard, the obtained data show (Fig. 2) that the respondents of the first group of directors with little experience to eliminate "professional deficiencies" are more prepared through their own development and 
the formation of management teams. Much less common is the choice in favor of delegating authority.

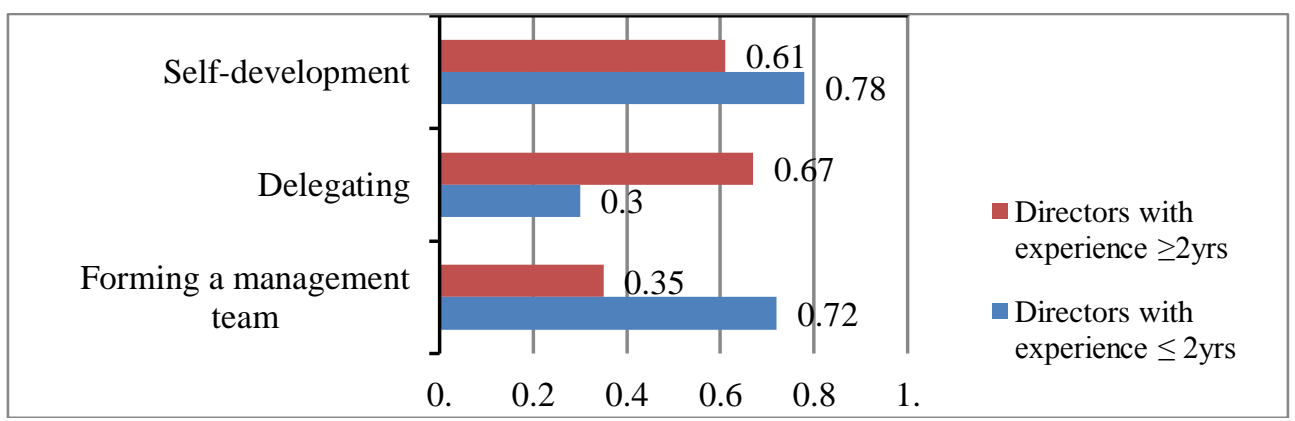

Fig. 1. Ways to meet the requirements of the professional standard of the head of an educational organization.

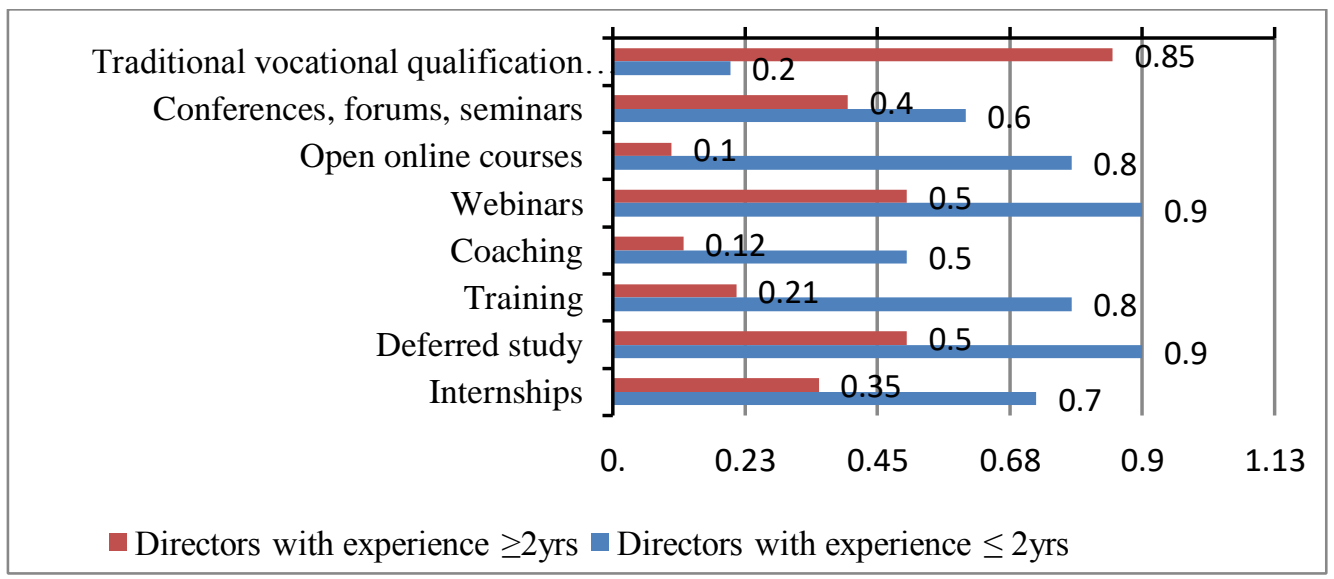

Fig. 2. Ways / methods of compensating deficits in professional competencies.

The results reflecting the frequency of elections by ways to increase compliance with the professional standard of the manager (Figure 1), show that the survey participants:

In the first group are more focused on their own development and the formation of a management team, which corresponds to modern trends,

In the second group of experienced directors, they focus on their own development and delegation of authority.

The ranking of methods / methods of training based on the frequency of occurrence among the respondents' elections is as follows as in (Fig. 2).

The affiliation of the directors to different generations manifested itself in the choice of preferred methods / methods of training and compensation of personal and professional deficits.

For experienced directors, the traditional system of additional professional education is the most important, conferences, webinars and distance learning are also preferred. The smallest number of elections falls on trainings, open on-line courses, mentoring. What is understandable from the point of view of the theory of generations - these forms have spread in recent decades. Mentoring, as an organized practice-oriented form of adaptation to the position of director, also resumed recently.

For directors with experience of up to 2 years, compensation of deficits is most acceptable in informative and informal form - in the format of webinars, distance learning, open online 
courses, internships. The traditional DPO system received the lowest number of responses, which differs from the responses of the previous group.

In accordance with the generalized labor functions of the head, presented in the Professional Standard, the necessary self-assessment of professional deficiencies was carried out by the necessary actions, skills and skills.

a) Knowledge

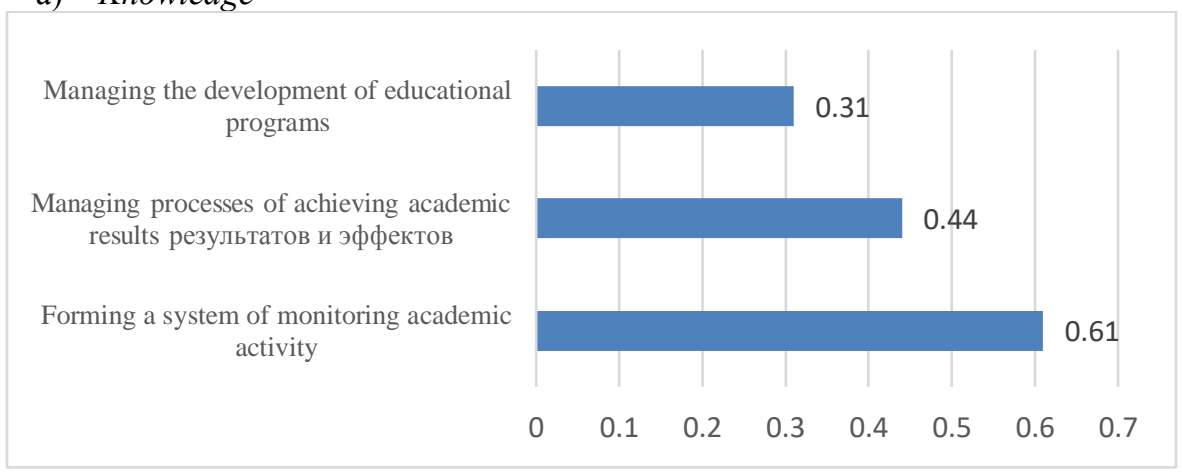

b) Actions

To coordinate the activity of all participants of academic relations

To change the basic program based on monitoring

To master the methods of monitoring the appraisal of the efficiency of the activity

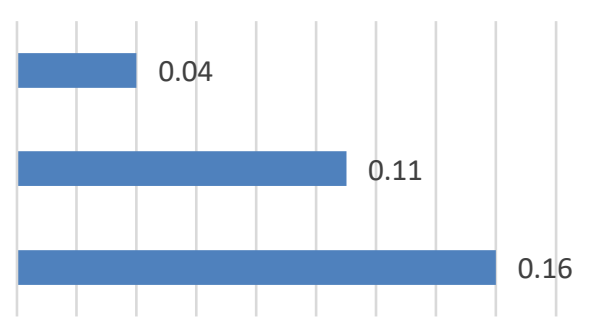

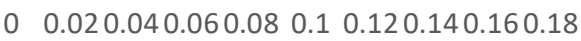

c) Skills

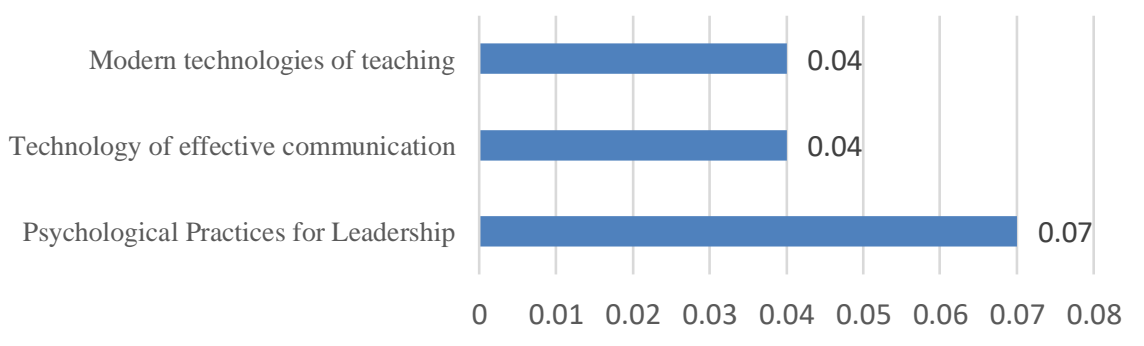

Fig. 3. Deficiency deficiencies in knowledge, skills and actions in the first generalized labor function of the Professional Standard "Managing educational activities". 
a) Knowledge

National and regional initiatives and priorities

Theory and methodology of strategic management

Theory and methodology of managing educational systems

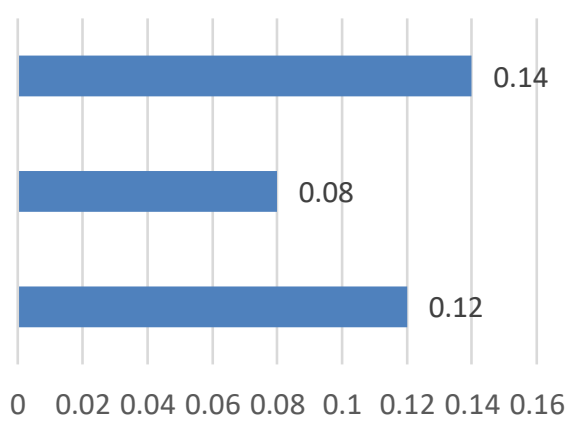

b) Actions

Assessing the limitations and risks of putting the development program

Arranging activity aimed at attracting resources

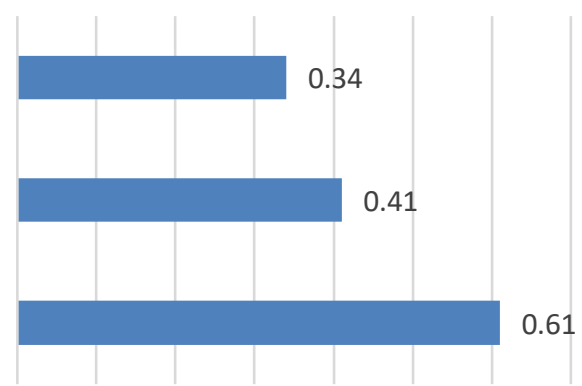

Developing marketing and monitoring the social demand for education

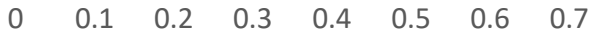

c) Skills

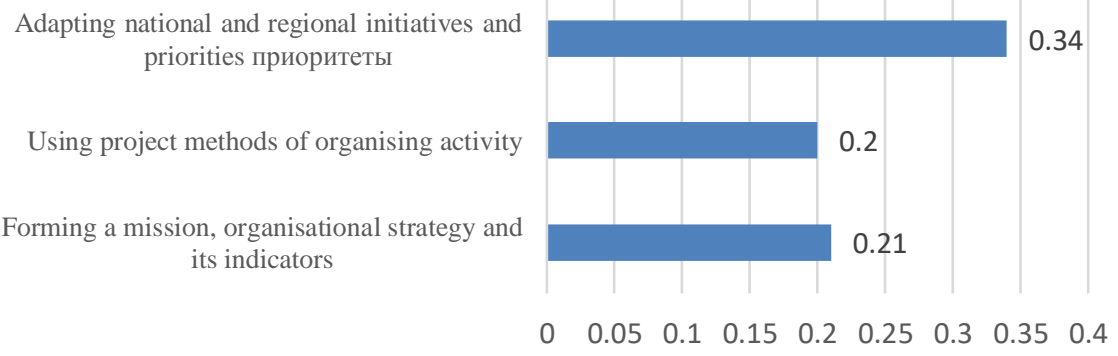

Fig. 4. Deficits of knowledge, skills and actions on the second generalized labor function of the Professional Standard "Leadership Development of Educational Organizations."

According to the first generalized function "Managing the Educational Activity of the Educational Organization", in actions, the interviewees have difficulty in managing the results taking into account the achievement of the goals (strategic aspect), the complexity in managing the development of educational programs. The most difficult is the practical process of forming a monitoring system for educational activities: lack of a systematic approach, lack of understanding of the purpose of this system, ignorance of tools and methods, and, as a consequence, the inability to integrate this system into the process (Figure $3)$.

There are not enough skills to use methods of analysis of internal and external monitoring with subsequent adjustment of educational programs; evaluation of the results and effects of the activities of the educational organization; coordination of activities with subsequent 
monitoring of all participants of educational relations in the implementation of plans and programs. There are not enough skills (experience) in creating professional pedagogical communities in the field of education and upbringing

In the aspect of lack of knowledge, the respondents focused on questions of the basics of practical psychology, the psychology of professional activity, and methods of effective communication.

There is a lack of up-to-date knowledge of educational technologies and means of teaching and upbringing, methods for monitoring and evaluating the educational achievements of trainees, and procedures for independent quality assessment.

Summarizing the revealed deficiencies of competencies in the second generalized labor function "Leadership development of the educational organization", one can note a low level of knowledge of the basics of marketing, the skills of using measuring marketing tools and methods of strategic management (Fig. 4).

The deficit in the skills to effectively implement the national and regional educational policy, to adapt the state priorities to strategic decisions in the development programs of educational organizations is revealed. The leader should be the conductor of state ideology and should not become a barrier to transformation. The lack of a strategic vision hinders the formation of the mission of the educational organization, does not allow the competent development of a development strategy, and applies modern methods and technologies of management. As a consequence - inability to manage changes in the organization, as well as motivate subordinates to achieve strategic goals. The managerial deficit is revealed in identifying the specifics of the organization, the ability to assess its competitive position, to apply methods for monitoring the implementation and evaluation of programs, plans, projects and results of activities, to own methods for analyzing the external and internal environment - which, as already indicated, is the lack of knowledge and skills in the field of the fundamentals of marketing and strategic management.

On the third labor function "Management of the resources of the educational organization", the actions revealed difficulties in monitoring, analyzing, evaluating, monitoring, generating reports on the effectiveness and effectiveness of resource use and management. Planning and ensuring a balanced distribution of all types (financial and economic, material, intangible, personnel, methodological, information resources) of resources, identifying possible risks associated with volume changes and the redistribution of resources.

A separate direction in the management of human resources identified difficulties in the formation of a system for assessing the quality of the human resource, incentive and incentive system, taking into account the specifics of the institution, as well as the organization of the selection and certification of personnel (Fig. 5).

Also, according to the survey, the actions connected with ensuring the procedure for concluding and executing economic and financial contracts (contracts), with local acts regulating the activities of the organization, cause difficulties.

There was a significant shortage in skills in the field of human resources management assessing the effectiveness of pedagogical and other workers, identifying professional deficits and workers' needs, using modern forms of continuous development of human resources, as well as owning methods for planning the development of professional and leadership skills. 
a) Knowledge

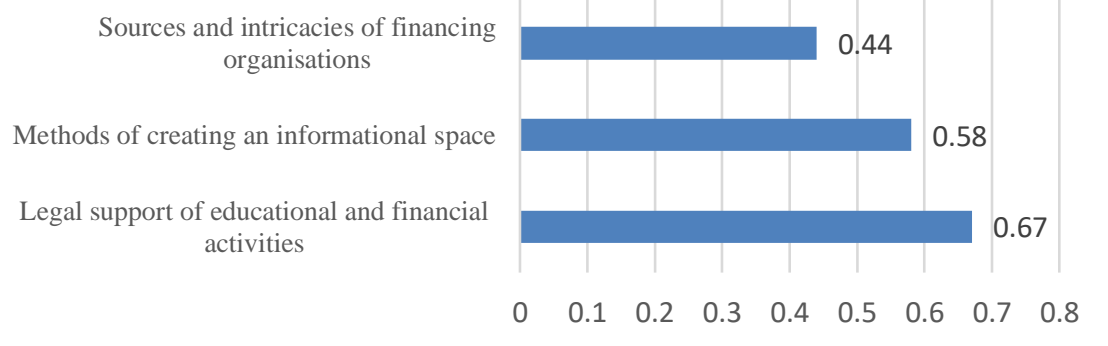

b) Actions

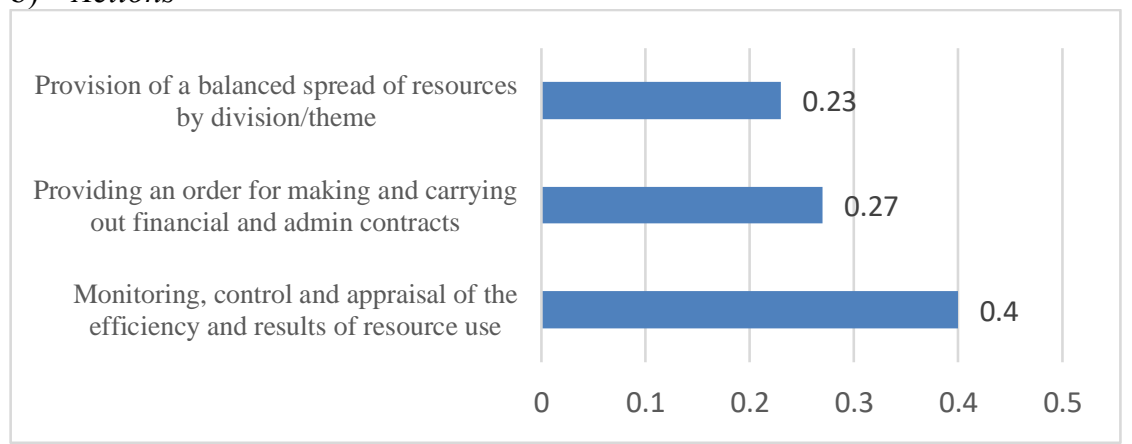

c) Skills

Forming managerial financial documents

Finding professional deficiencies and needs of employees

Assessing risks of carrying out financial and admin activity

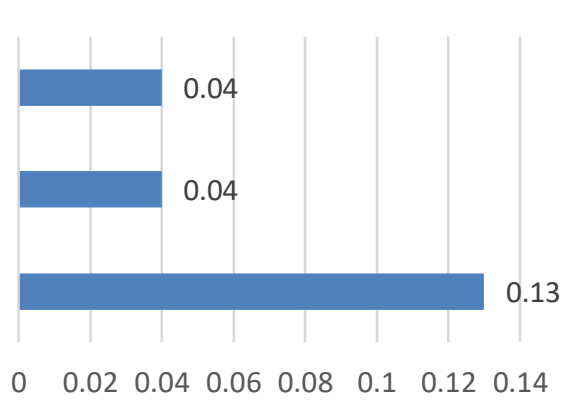

Fig. 5. Deficits of knowledge, skills and actions in the third generalized labor function of the Professional Standard "Managing the resources of the educational organization of the educational organization".

There was a lack of skills in the management of financial resources: in the formation of financial and management documents, in the alignment of budget items in accordance with the organization's strategy; risk assessment; monitoring compliance with obligations.

According to the results of the survey, there was a lack of knowledge of the regulatory framework in the field of resource management at various levels: from federal and regional to local acts of the organization; lack of managerial knowledge on the management of almost all types of resources: financial and economic, material, intangible, personnel, methodological, information resources. Lack of knowledge of tools and methods: methods for monitoring the effective use of resources, methods for monitoring and analyzing the need for necessary resources, methods for planning and forecasting, and methods for assessing risks and ways to minimize them in resource management. Also, an important gap in knowledge for today - the principles and methods of building an information space in an 
educational organization, the technology of communication channels in the organization and ways of protecting information, has also been discovered.

According to the fourth labor function, "The representation of the educational organization in relations with state authorities, local government, public and other organizations" causes difficulties - identifying partners, actors and interaction formats, organizing the process itself, and in the absence of a clear structure of interaction - the inability to evaluate this process, which hinders the development and improvement of the process of interaction between educational organizations and state authorities, social partners and the local community.

The lack of skills to build constructive relationships, oral and written communications with various actors, interaction with government authorities, participants in educational relations, social partners and the local community, and education management bodies on the issues of external monitoring are revealed.

With a low percentage of answers in the "knowledge" category in the previous three sections, in the fourth generalized function the situation changes, and this section is the second most relevant topic. The lack of knowledge on the normative component of their rights and duties, algorithms of interaction with the external environment is revealed. Hence, as a consequence, the inability to competently defend their interests when interacting with counterparties. Misunderstanding of principles, methods, mechanisms and technologies of interaction (including network), requirements for interaction between the educational organization and state authorities, as well as the basic principles of state-public management of the educational organization.

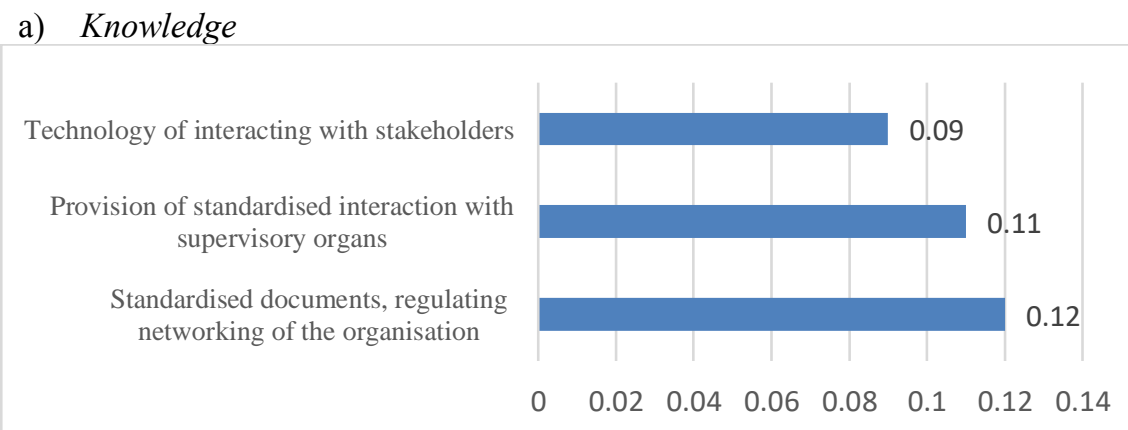

b) Actions

Organising interaction with social partners, local community partaking

Appraising the results of interaction with the external environment

Defining subjects and formats of cooperation

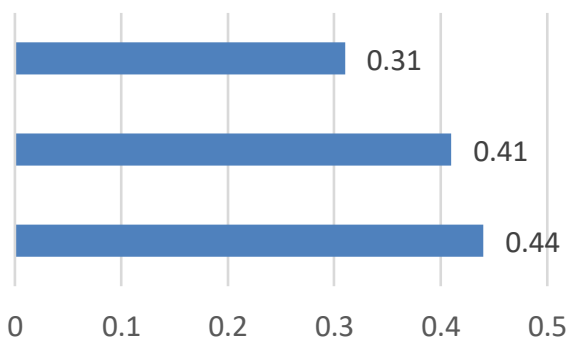

c) Skills 
Organising communication with organs of educational management

Having skills at creating constructive cooperation

Carrying out control and appraisal of the effectiveness of the cooperation and representing the organisation's interests

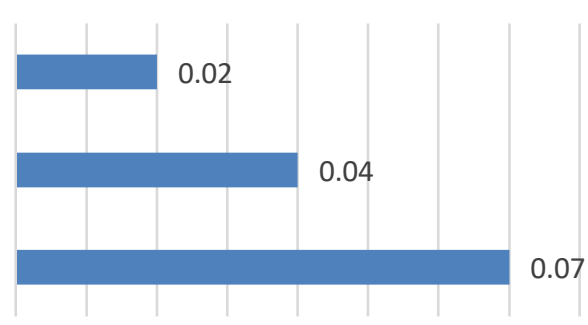

$\begin{array}{lllllllll}0 & 0.01 & 0.02 & 0.03 & 0.04 & 0.05 & 0.06 & 0.07 & 0.08\end{array}$

Fig. 6. Deficits of knowledge, skills and actions on the fourth generalized labor function of the Professional Standard "Representation of an educational organization in relations with public authorities, local authorities, public and other organizations".

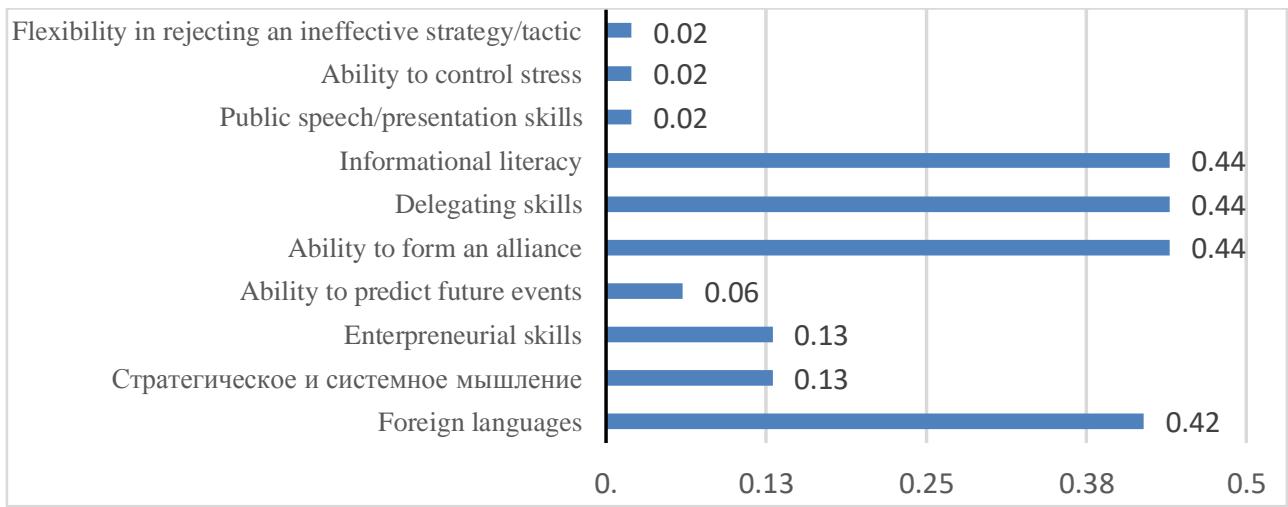

Fig. 7. General competencies (soft skills).

The last area of research is the identification of deficiencies in general competencies (soft skills) for school principals. In the list of missing general competencies following the results of the online survey, an unquestionable leader is the knowledge of foreign languages - at this point slightly less than half of the respondents noted. Behind him, with a backlog, are the skills of strategic and systemic thinking, entrepreneurial skills, the knowledge of the foundations of management and the ability to apply them in practice, the so-called managerial abilities: the skills of delegation of authority, the ability to form an effective team of likeminded people, knowledge in planning, IT literacy. Also, the imperfection of personal qualities, such as ability to control stress, flexibility, ability to foresee the development of events, objectively and realistically to evaluate them, were especially noted.

The results of the study on the identification of soft skills deficits in school principals are presented in (Fig. 7).

\section{Methods}

Based on the established interrelationships of ways to improve compliance with the requirements of the professional standard and plans for their own professional development in terms of content and forms of training, it is possible to determine the preferred options (models) for the professional development of the head of the educational organization. More experienced directors, with accumulated professional luggage, need a constant upgrade, in line with new social and economic challenges. Forms of education, preferred in this cohort of respondents, somewhat do not meet this rapid need for compensation of local deficits. 
Transition to new informational and informal forms - open courses, webinars, trainings. professional Internet communication will happen on its own, but to catalyze the process, it may be necessary to stimulate the activities of educational authorities, through the system of attestation and financial mechanisms. Directors with experience up to two years belong to other generations, they themselves prefer quick, active forms of compensation of deficits, but for them the basic training is required for the normative and financial support of the activity of the educational organization, for strategic management, and for personnel management. As the results of the international study of TALIS 2013 show, the number of Russian directors who received the opportunity to undergo school management prior to taking office is $6.45 \%$ of the total number of respondents (in the countries that are leaders of international studies, the proportion of trained directors reaches 70\%) [19]. Therefore, candidates for heads of the educational organization need to go through the traditional system of additional vocational education, to receive formal education. Ideally, to pass through selection tests and training under an individual program in the personnel reserve, then, when taking office, be assigned to a mentor-experienced school supervisor, and then to reinforce knowledge and skills in forms of informational and informal education characteristic of this category of respondents [20-22].

It seems interesting to continue the research in dynamics and in the context of the theory of generations, since the leaders of educational organizations are bright charismatic representatives of their generations, with pronounced preferences, a set of competences, inclinations. In the Russian Federation, given the huge size of the country and regional diversity, it would be interesting to track regional differences in the professional orientations and needs of school principals.

\section{References}

1. D. L. Goetsch, S. B. Davis, Quality management for organizational excellence (Pearson, Upper Saddle River, 2014)

2. $\quad$ K. U. Kishore, R. S. Reddy, U.S. Patent No. 9,736,030 (Patent and Trademark Office, Washington, DC, 2017)

3. B. J. Hoffman, B. H. Bynum, R. F. Piccolo, A. W. Sutton, AMG, 54, 4, 779-796 (2011)

4. P. G. Northouse, Leadership: theory and practice (London, Sage Ppublications, 2018)

5. D. Boud, R. Cohen, J. Sampson, Peer learning in higher education: learning from and with each other (London, Routledge, 2014)

6. S. S. Neustroev, S. N. Ryagin, EMTP, 3, 19 (2004)

7. S. S. Neustroev, A. V. Simonov, Chelovek i Obrazovaniye, 3, 44 (2015)

8. Yu. M. Fedorchuk, Yu. V. Polyaninova, EMTP, 1, 25 (2017)

9. Yu. M. Fedorchuk, S. S. Neustroev, Yu. V. Polyaninova, Yu. A. Chekulaeva, V. S. Ilyina, A. V. Bazhilina, M. V. Komarova, SN RAO UES, 3 (2017)

10. M. B. Bakhtin, S. E. Dovbysh, A. A. Arinushkina, V. S. Molchanova, EMTP, 3, 27 (2017)

11. A. A. Arinushkina, EMTP, 4, 24 (2016)

12. Institute of Education Management of the Russian Academy of Education, Questionnaire (https://goo.gl/forms/DbZ0h6iAwDTcIJ6j2, 2018)

13. Garant, Draft of the professional standard "Head of Educational Organization" (http://www.garant.ru/products/ipo/prime/doc/56574265, 2018) 
14. Institute of Education Management, Materials of the I and II all-Russian scientific and practical conference "Professional Development of the Leaders of Educational Organizations Conducted by the of RAO” in 2016, 2017 (http://iuorao.ru/index.html, 2018)

15. T. Brabazon, From revolution to revelation: Generation $X$, popular memory and cultural studies (London, Routledge, 2017)

16. G. O'Bannon, Public Personnel Management, 30, 1 (2001)

17. A. B. Acar, International Journal of Business and Social Science, 5, 5 (2014)

18. K. J. Johns, Exploring the motivational and hygiene factors of baby boomers, generation $X$, and millennials in the workplace (Scottsdale, Northcentral University, 2017)

19. E. Lenskaya, M. Pinskoy., Russian teachers in the mirror of the international comparative study of the pedagogical corps (TALIS 2013) [Text] / ed.; Nat. Issled. UHSE IE. Moscow: 2015.

20. R. M. Thomas, T. N. Postlethwaite, Schooling in East Asia, forces of change: formal and nonformal education in Japan, the Republic of China, the Peoples Republic of China, South Korea, North Korea, Hong Kong, and Macau (Amsterdam, Elsevier, 2014)

21. P. R. Britto, M. Oketch, T. S. Weisner, Nonformal education and learning (New York, 2014)

22. E. F. Thomas, Education and social participation: civic identity and civic action in formal and informal education contexts (New York, SSH EC, 2017) 